\title{
RESENHA
}

OLIVEIRA, Adilson J. A. A busca pela compreensão cósmica. São Carlos: EdUFSCar, 2010.

\section{A BUSCA PELA COMPREENSÃO CÓSMICA. CRÔNICAS PARA DESPERTAR O INTERESSE PELA FÍSICA E A CIÊNCIA EM GERAL}

Rodrigo Drumond Vieira*

O livro em análise foi escrito por Adilson J. A. de Oliveira, professor do Departamento de Física da Universidade de São Carlos e responsável por vários projetos referentes à divulgação científica. $\mathrm{O}$ autor apresenta, logo nas primeiras páginas do prefácio, o fascínio que a Astronomia e a Ciência em geral lhe despertaram desde tenra idade. Carl Sagan, reconhecidamente um dos maiores divulgadores da Ciência do século XX, tem sua série para televisão "Cosmos" apontada como uma grande fonte de incentivo e estímulo para o autor na sua relação com o conhecimento científico.

Ainda no prefácio, o autor destaca que muitas vezes estamos sujeitos a um volume enorme de informações oriundas da mídia, internet, etc. O autor reconhece que a publicação deste livro de divulgação é importante pela possibilidade que oferece para uma leitura mais pausada e reflexiva sobre Ciência, favorecendo e complementando o entendimento das pessoas sobre o que é e para que serve este empreendimento humano, tão presente e necessário no cotidiano de todos.

A obra é composta por "crônicas" sobre diversos temas de Ciência, em especial sobre Astronomia e Física, que foram publicadas originalmente em sites do AOL, Web São-Carlos e ClickCiência. As "crônicas" foram publicadas e escritas em épocas diferentes e a sua organização neste livro segue um padrão recursivo, em que uma mesma ideia é abordada segundo diferentes contextualizações, como é o caso da Teoria da Relatividade Especial. Essa "recursividade contextualizada" facilita a compreensão do leitor das temáticas abordadas. As crônicas foram agrupadas segundo campos específicos, como em "Crônicas sobre o Saber", "Crônicas sobre a Matéria", "Crônicas sobre o Cosmos", "Crônicas sobre o Espaço e Tempo" e "Crônicas sobre a Vida". Apesar dessa estrutura, as crônicas são independentes e podem ser lidas em qualquer ordem.

Em "Crônicas sobre o Saber", o autor inicialmente desenvolve argumentos a favor da importância do entendimento do conhecimento científico por 
todas as pessoas. O caráter essencialmente humano da Ciência é discutido com exemplos, inclusive de fraudes, as quais resultam de ambições pessoais dos cientistas. O autor prossegue fazendo apologia ao conhecimento básico como forma de evitar engodos na navegação da web, em um momento em que temos a disposição uma vastidão de conhecimentos sem, entretanto, que todo esse conhecimento tenha compromisso com a sua confiabilidade. As mecânicas newtoniana, relativística e quântica são introduzidas segundo seus campos de aplicação e a teoria das supercordas é apresentada como uma possível síntese de "tudo". O autor adverte ainda que, apesar da coerência interna dessa nova abordagem teórica, ela ainda carece de comprovação empírica. Com o exemplo da teoria heliocêntrica, o autor aborda a questão da temporalidade que uma ideia ou teoria necessita para ser aceita, tendo como obstáculos os dogmas da igreja e outras constrições. Esse conjunto de crônicas é finalizado com a opinião de que o conhecimento pode ser uma solução para medos, apesar de sempre lidarmos com incertezas, inclusive na Ciência, como é apontado para o caso do princípio da incerteza na mecânica quântica.

Em "Crônicas sobre a Matéria”, são abordados inicialmente temas como o papel da imaginação na Ciência, a revolução tecnológica atual com o advento da nanotecnologia e as supercordas como suposta teoria unificadora. $\mathrm{O}$ autor discute a importância do Sol para a manutenção do ciclo da vida na Terra, introduzindo elementos de conhecimento do campo da Biologia. A natureza dual da luz e a importância dos elétrons na vida contemporânea são alguns dos exemplos que o autor utiliza para introduzir elementos da Física do século XX. O magnetismo e o spin são apresentados como promissores de novas tecnologias em processamento e armazenamento de dados. Na sequência o autor aborda a questão do aumento constante da entropia do universo, o que resulta em uma concepção sobre o seu destino. O histórico de descoberta dos planetas e seu batismo com nomes de deuses é traçado e a lenda de Ícaro é apresentada como metáfora para os riscos inerentes à conquista espacial, a qual é comparada com o advento das grandes navegações. Na sequência, o autor explica como as estrelas podem ser usadas como fontes de referência, além de apresentar os diversos estágios que as estrelas percorrem ao longo de sua vida. A origem do universo sob as perspectivas da mecânica newtoniana e relativística são discutidas e descobertas do século XX são apresentadas como evidência para a solução relativística. Finalizando essas crônicas, o autor apresenta a problemática do mistério da escuridão noturna, a qual é atribuída à finitude e inflação do universo.

Em "Crônicas sobre o Espaço e Tempo", o autor mostra como as ideias de Newton foram influentes, posteriormente questionadas, e, não obstante o seu questionamento, é salientado que elas ainda possuem um amplo campo da aplicação na sociedade contemporânea. Os cinco artigos que Einstein publicou no início do século XX são introduzidos, e o autor dá ênfase à Teoria da Relatividade Especial e suas consequências para o nosso entendimento sobre espaço e tempo. Ainda referindo-se ao trabalho de Einstein, o autor apresenta as 
implicações da revolucionária equação $\mathrm{E}=\mathrm{mc}^{2}$, e a sua aplicabilidade no entendimento dos processos de fusão e fissão nuclear. A seguir, são apresentados os princípios básicos da Teoria da Relatividade Geral, dando-se destaque ao princípio de equivalência. O autor explica que essa teoria foi validada em 1919 com observações de estrelas em uma situação de eclipse solar, as quais foram realizadas em Sobral, Ceará, e nas Ilhas Príncipe, África. Finalizando esse conjunto de crônicas, as incríveis velocidades atingidas por naves espaciais são comparadas com a intangível velocidade da luz; o tempo contínuo e a possibilidade de discretizá-lo são apresentados; a motivação para discretizar o tempo é traçada tendo em conta a tentativa de obter uma descrição mais completa dos fenômenos físicos, superando a incompatibilidade no nível microscópico entre mecânica quântica e relatividade.

Em "Crônicas sobre a Vida", o autor foca inicialmente a Física das competições esportivas, explicando como o entendimento de Física ajuda a superar os limites humanos. Tais limites também são explorados quando o autor aborda a questão dos super-heróis e a implausibilidade física dos seus superpoderes no universo em que vivemos. A importância da água para a criação e manutenção da vida é abordada, juntamente com a necessidade de consumo de energia de alta qualidade. Finalizando esse conjunto de crônicas, a estrutura e função do DNA são apresentadas como condição para a emergência da vida tal como a conhecemos.

Em "Uma Última Crônica", o autor reflete sobre os capítulos precedentes e advoga que o saber científico é um dos mais bem sucedidos empreendimentos da humanidade. $\mathrm{O}$ autor finaliza o livro reforçando a ideia de que o acesso ao conhecimento científico, mesmo que parcial, é importante para todas as pessoas.

O conjunto da obra é acessível ao público universitário iniciante e a pessoas que já têm inclinação e interesse por Ciências. Devido ao seu linguajar simples, à recursividade e à contextualização dos temas abordados, o livro permite também que professores do Ensino Médio o utilizem como fonte complementar de referência para suas aulas. Nesse sentido, o livro avança o campo de divulgação de ideias consideradas "contrasensuais" e de difícil entendimento, como os princípios da mecânica quântica e da relatividade, e suas consequências para o nosso entendimento do universo e da nossa relação com ele.

Resta questionar se o Ensino Fundamental e a Educação de Jovens e Adultos, devido às suas peculiaridades, podem também se favorecer com o livro. Esse questionamento é relevante, já que os trabalhos de divulgação científica sempre pressupõem um público específico. Ideias como o "princípio da incerteza" e "dilatação do tempo" são desafiadoras e carecem de divulgação apropriada para o Ensino Fundamental e jovens e adultos que deixaram os estudos há muito tempo e estão novamente retomando sua formação básica. 
Data de recebimento: $10 / 02 / 2011$

Data de aprovação: $11 / 03 / 2011$

Data da versão final: $11 / 03 / 2011$ 